\title{
8. GAS HYDRATE AND SEDIMENT GAS COMPOSITION, HOLE 892A ${ }^{1}$
}

\author{
Martin Hovland, ${ }^{2}$ David Lysne, ${ }^{3}$ and Michael Whiticar ${ }^{4}$
}

\begin{abstract}
Hole $892 \mathrm{~A}$ is located above a prominent bottom-simulating reflector (BSR) and a steeply dipping thrust fault. Gas hydrates and high sediment gas concentrations were therefore expected to be encountered in the hole. Gas hydrates were found and sampled, but only within the near-surface sediments, down to about 19 meters below sea floor (mbsf). Also as expected, there were relatively high sediment hydrocarbon gas concentrations in some zones, but not at the BSR at $73.9 \mathrm{mbsf}$. Finally, there were a few other unexpected organic geochemical results: (1) Very high concentrations of hydrogen sulfide $\left(\mathrm{H}_{2} \mathrm{~S}\right)$ and methane $\left(\mathrm{CH}_{4}\right)$ were found in the near-surface sediments. (2) At $68 \mathrm{mbsf}$ there was an abrupt transition from a domination of bacterial gases to gases of thermal origin. (3) The visible gas hydrates contained a high proportion of $\mathrm{H}_{2} \mathrm{~S}$.

Even though anomalously low temperatures were measured in some cores, and discrete layers of depleted chlorinity were found, indirectly suggesting intercalated layers of disseminated gas hydrates, down to a depth of $68 \mathrm{mbsf}$, no visible gas hydrates were found deeper than $19 \mathrm{mbsf}$. The $68 \mathrm{mbsf}$ boundary is termed the "geochemical BSR". Theoretical hydrate stability calculations based on the geochemical and temperature observations in Hole 892A, provide somewhat surprising results: hydrates are found to be very stable down to $15.2 \mathrm{mbsf}$, where the stability decreases dramatically down to $21.7 \mathrm{mbsf}$, and then they become unstable at $45 \mathrm{mbsf}$, and only conditionally stable below that depth. The stability conditions below $45 \mathrm{mbsf}$ are governed mainly by variations in the propane content of the gas mixture and by local temperature deviations from the general geothermal gradient. The results from this study therefore, do not support the widely held notion that the geophysical BSR directly corresponds with the base of gas hydrate stability zone.
\end{abstract}

\section{INTRODUCTION}

The natural gas hydrates belong to a class of compounds called true clathrates, where a crystal lattice of hydrogen-bonded water molecules encase gas molecules in cavities. The gas molecules, also called guest molecules, stabilize the crystal lattice through weak van der Waal's interactions. There are 3 types of crystal structures that have been identified with a large number of guest molecules. These are the classic Structures I and II, and the recently discovered Structure $H$ (Ripmeester et al., 1994). A detailed description of the latter structure is not yet available. The $12-\AA$ cubic unit cell of the water crystal lattice of Structure I contains 2 pentagonal dodecahedra and 6 tetrakaidecahedra cavities. Methane and hydrogen sulfide molecules fit into both of these cavities; ethane and carbon dioxide molecules can only fit into the large cavity of Structure I hydrate. The $17.3-\AA$ cubic unit cell of Structure II contains 16 pentagonal dodecahedra and 8 hexakaidecahedra cavities. Hydrocarbon gases like propane, isobutane and n-butane can only fit into the large cavity of Structure II. Natural gas mixtures with low to moderate propane or isobutane content usually form Structure II hydrate.

Because it has been proposed that natural gas hydrates may store enormous quantities of methane in marine sediments, the origin of bottom-simulating reflectors (BSRs) and the amounts of hydrate and free gas associated with them may be important for assessing their economic potential, their role as a submarine geohazard, and their effect on global climate change (Kvenvolden and Barnard, 1983; Ginsburg et al., 1993). The origin of the velocity or bulk density contrast

'Carson, B., Westbrook, G.K., Musgrave, R.J., and Suess, E. (Eds.), 1995. Proc. ODP, Sci. Results, Vol. 146 (Pt. 1): College Station, TX (Ocean Drilling Program). ${ }^{2}$ Statoil, P.O. Box 300, N-4035 Stavanger, Norway.

${ }^{3}$ SINTEF, N-7034 Trondheim, Norway.

${ }^{4}$ SEOS, University of Victoria, British Columbia V8W 2Y2, Canada. that causes the abrupt and dramatic decrease in acoustic impedance immediately below the BSR, and its association with gas hydrates, is controversial. Various models, mainly based on analyses of reflection seismic data, exist: either the BSR has been interpreted as the base of a high-velocity layer caused by hydrates cementing the sediments above (Hyndman and Davis, 1992), as the top of a low velocity zone caused by free gas beneath the BSR (Singh et al., 1993; Bangs et al., 1993), or a combination of both (Dillon and Paull, 1983; Minshull and White, 1984; Miller et al., 1991).

The necessary conditions for inducing the formation of gas hydrates in nature are controlled by an interrelation among various factors including temperature, pressure and the availability of natural gases (Sloan, 1990). Because water makes up the main body of gas hydrate the sediments must obviously contain sufficiently amounts of free water. In ocean sediments the hydrate equilibrium conditions are also affected by salt ions, which lowers the hydrate equilibrium temperatures, and the presence of larger gas molecules like propane and isobutane (in the methane-dominated gas mixture), which increase the hydrate equilibrium temperatures. In addition, several models for the formation of natural gas hydrates and BSRs imply that their existence signifies an active fluid flux through or past the zone containing the gas hydrates (Trofimuk et al., 1972; Hyndman and Davis, 1992; Soloviev and Ginsburg, 1994). From laboratory experiments it is known that a gas hydrate lense or plug (without sediments) can be a porous and permeable medium that permits gas and water to flow through (Lysne, 1994). However, laboratory experiments have shown that a hydrate-cemented sand formation can hold a pressure gradient of up to $1379 \mathrm{bar} / \mathrm{m}$ (Cheng, 1975).

Visible gas hydrates were sampled at Site 892 of ODP Leg 146, but not as thick, massive layers, only as centimetric irregular clear nodules and white, millimetric pellets embedded in soft clays and accumulating shallower than 19 mbsf. Naturally occurring offshore (marine) gas hydrates have been previously recovered and sampled from a variety of locations, ranging from the Gulf of Mexico to the 
Sea of Okhotsk (described and reviewed in Sloan, 1990; Brooks et al., 1986; Field and Kvenvolden, 1985; Kvenvolden, 1993; Soloviev and Ginsburg, 1994). In Hole 892A there was also indirect evidence of the in situ occurrence of gas hydrates at depths below 19 mbsf. The evidence was in the form of sediment layers with anomalously high water content that Westbrook et al., (1994) called "soupy layers" and with lowered interstitial-water chloride values (Westbrook, Carson, Musgrave, et al., 1994).

The observations from ODP Leg 146 off Vancouver and Oregon, where two prominent BSRs were drilled, sampled, and imaged by use of VSP (vertical seismic profiling) have established that the BSR must be somehow related to the presence of gas hydrates above the BSR and free interstitial gas in the sediments below the BSR (MacKay et al., 1994). However, numerous questions about the link between migrating gas, the BSR, the gas hydrates and their stability field still remain controversial. We will discuss the observations of gas composition of sediments and gas hydrates in Hole 892A of ODP Leg 146, which penetrated a prominent BSR off Oregon, at $73.9 \mathrm{mbsf}$ (MacKay et al., 1994).

\section{FREE AND INTERSTITIAL SEDIMENT GASES}

As outlined in the Initial Reports volume (Westbrook, Carson, Musgrave, et al., 1994), two sets of results exist that characterize the gases in the sediments of Hole 892A:

1. The expansion void gases (EVG), which were acquired from gas pockets observed in the transparent core liner and were sampled directly from the core liner by piercing it with a valved, double-ended syringe needle (Fig. 1). Thereafter, the valve was opened and gas was drained into a $20-\mathrm{cm}^{3}$ pre-evacuated rubber-sealed glass container (Vacutainer ${ }^{\mathrm{TM}}$; Westbrook, Carson, Musgrave, et al., 1994). EVG samples thus include free gases, gases exsolved from the sediment pore water system, and gases released from gas hydrates dissociating because of pressure release.

2. The headspace gases, which were acquired by sampling the sediments with a cork borer immediately after retrieval on deck. Cylindrical sediment samples of $3-5 \mathrm{~cm}^{3}$ were placed in sealed glass serum vials $\left(21.5 \mathrm{~cm}^{3}\right)$ and put in an oven at $60^{\circ} \mathrm{C}$ for $30 \mathrm{~min}$ prior to gas sampling. In the case of consolidated or lithified sediments, chips of material were placed in the vial and sealed. A $5 \mathrm{~cm}^{3}$ volume gas sample of the headspace gas in the vial was then extracted with a standard glass syringe for each analysis for gas chromatography. The headspace gases represent interstitial gases bound to the sediment grains by a film of water (formation water) and released from the sediments by high temperature.

Because the voids observed in the plastic coreliner caused by gas expansion in Hole 892A ranged in width from about $5 \mathrm{~mm}$ up to about $50 \mathrm{~cm}$, the EVG samples do not provide information on the absolute free sediment gas concentrations. In the following, only the EVG gas composition will therefore be discussed.The total number of EVG samples in Hole $892 \mathrm{~A}$ was 17 , ranging from a minimum depth of 1.78 mbsf to a maximum depth of $165.82 \mathrm{mbsf}$ (Westbrook, Carson, Musgrave, et al., 1994). Because the random distribution of expansion voids in the core-liners, and the uneven distribution of intact sediment samples in the core-liners (total core recovery in Hole $892 \mathrm{~A}$ was only $35 \%$ ), the distance between each EVG sample ranges from $1.77 \mathrm{~m}$ to $21.09 \mathrm{~m}$. Even so, the $17 \mathrm{EVG}$ samples provide a relatively good documentation of the vertical distribution of the total gas composition within the sediments at Site 892 . The total number of headspace gas samples in Hole $892 \mathrm{~A}$ was 24 , which were evenly distributed throughout the hole.

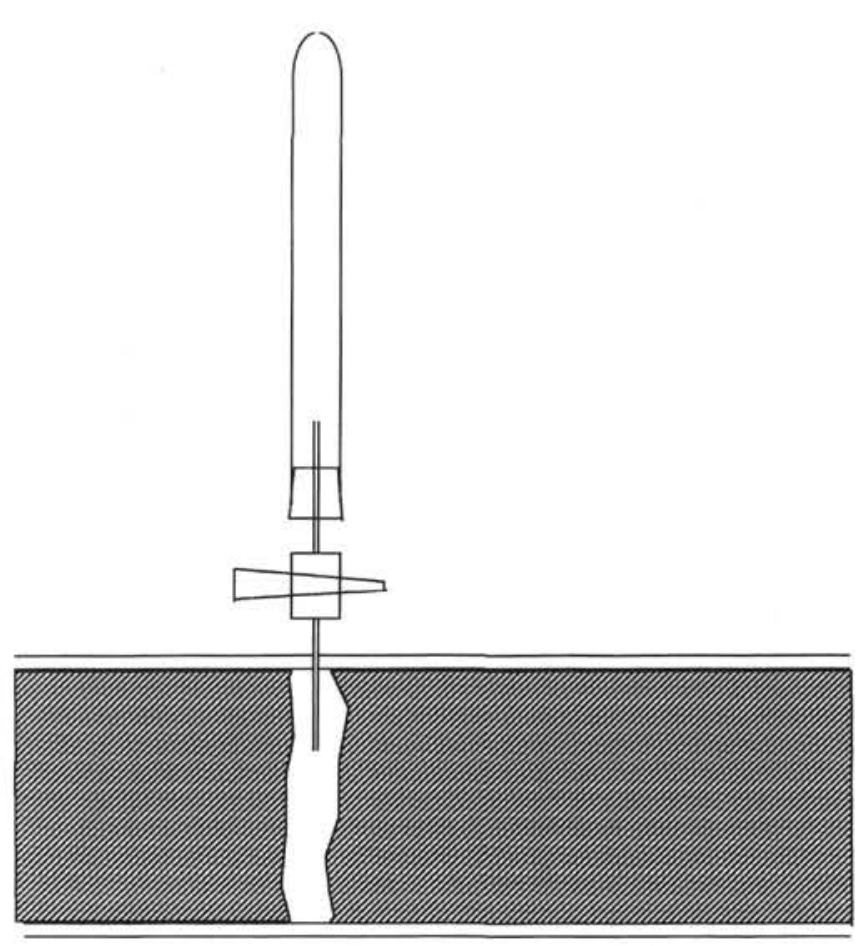

Figure 1. Sketch showing sampling method for expansion void gases (EVG). The transparent plastic coreliner gas been pierced by a valved, double-ended syringe needle at an expansion void. A Vacutainer ${ }^{\mathrm{TM}}$ tube is fitted on the other end before the valve is opened.

\section{$\mathrm{H}_{2} \mathrm{~S}$ Values}

Very high EVG $\mathrm{H}_{2} \mathrm{~S}$ concentrations were found in Hole $892 \mathrm{~A}$, at $1.75,3.55$, and at $15.15 \mathrm{mbsf}$. Although the exact concentrations are uncertain because of a lack of suitably high calibration standards on board ship, the concentrations exceed 9000 ppmv (parts per million by volume) at $1.75 \mathrm{mbsf}$ and remain high (about $6000 \mathrm{ppmv}$ ) to at least a depth of 15.15 mbsf. Below the BSR (at 73.9 mbsf) no $\mathrm{H}_{2} \mathrm{~S}$ was found (Fig. 2D). However, only trace amounts of $\mathrm{H}_{2} \mathrm{~S}$ were found in the headspace gases of Hole 892A (at 1.51 and at 12.53 mbsf). The high $\mathrm{H}_{2} \mathrm{~S}$ content is found at the same depths as the visible gas hydrates were sampled, and because $\mathrm{H}_{2} \mathrm{~S}$ will be concentrated in the hydrate phase, it is concluded that the sampled $\mathrm{H}_{2} \mathrm{~S}$ has its origin from gas hydrates that dissociated on recovery.

\section{$\mathrm{CO}_{2}$ Values}

The EVG $\mathrm{CO}_{2}$ distribution profile (Fig. 2C) displays one distinct spike at 137.13 mbsf, where the percentage increases to nearly $4 \%$, which is more than ten times the average $\mathrm{CO}_{2}$ value for most of the other EVG samples in the hole. The headspace $\mathrm{CO}_{2}$ concentration profile also displays a distinct spike (Fig. $3 \mathrm{~F}$ ), but at a shallower depth, 116.99 mbsf, even though headspace samples have been acquired near the $137.13 \mathrm{mbsf}$ level where the EVG spike occurred. We suggest that the two spikes may be related, but that the two profiles do not correlate because of different transport and storage mechanisms for $\mathrm{CO}_{2}$ in pore water (EVG), as opposed to formation water (headspace). In the headspace $\mathrm{CO}_{2}$ concentration profile for Hole $892 \mathrm{~A}$ there are two other peculiarities worth noting: (1) low $\mathrm{CO}_{2}$ concentrations in the high $\mathrm{H}_{2} \mathrm{~S}$ zone (i.e., between 3 and $19 \mathrm{mbsf}$ ); and (2) very low $\mathrm{CO}_{2}$ concentration, 334 ppmv, at 79.63 mbsf, immediately below the BSR. 

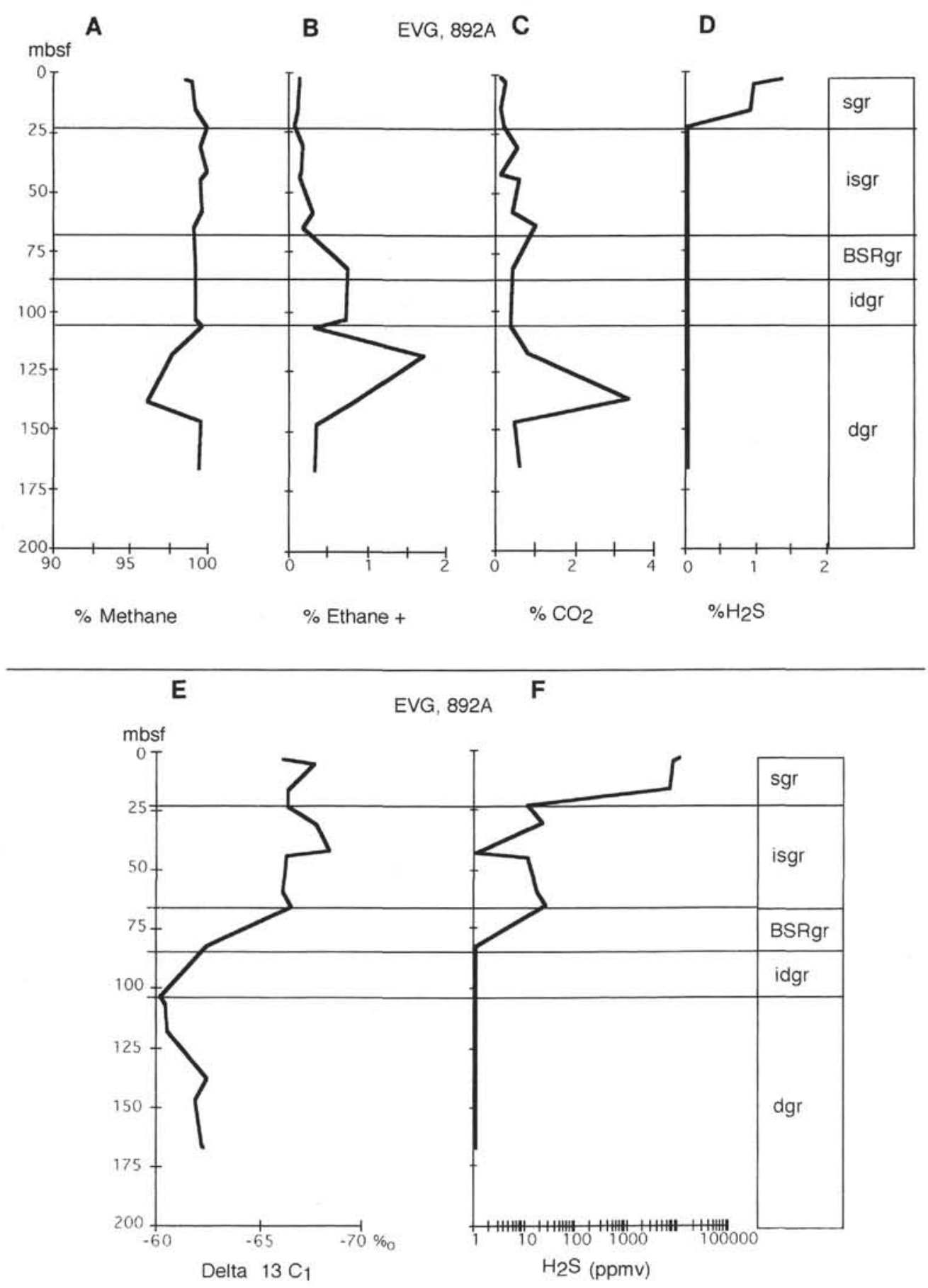

Figure 2. A-D. Percentage plots of expansion void gases: all hycrocarbon gases, $\mathrm{H}_{2} \mathrm{~S}$, and $\mathrm{CO}_{2}$. E. Stable carbon isotope ratio, $\delta \mathrm{C}^{13}$ (PDB) for EVG methane. F Concentration of EVG $\mathrm{H}_{2} \mathrm{~S}$ (note logarithmic scale). The abbreı tions denote the various gas regimes, discussed in the text $(\mathrm{sgr}=\mathrm{shallow}$ gas regime, isgr = intermediate shallow gas regime; $\mathrm{BSRgr}=\mathrm{BSR}$ gas regime; idgr = intermediate deep gas regime; dgr = deep gas regime).

\section{Methane Values}

The EVG (Fig. 2A) and headspace $\mathrm{CH}_{4}$ profiles (Fig. 3A) differ significantly in that the headspace $\mathrm{CH}_{4}$ concentrations are highest (about 130,000 ppmv) only near the surface (at 3.67 and $12.53 \mathrm{mbsf}$ ), whereas the EVG profile is dominated by $\mathrm{CH}_{4}(95 \%-99 \%)$ throughout. This indicates the presence of at least some free (EVG) methane at and below the BSR at 73.9 mbsf. However, in the headspace profile across the BSR-level, there is a sharp reduction in the $\mathrm{CH}_{4}$ concentration, which suggests that the methane at the BSR is not contained interstitially in the sediment formation water, but exists in free form or partly dissolved in the pore water system or contained in dissociated gas hydrates.

The stable isotope values for EVG methane (Fig. 2E) have been determined subsequent to the shipboard gas analyses. The values range from a $\delta^{13} \mathrm{C}$ value of $-67.5 \%$ (PDB) at $3.55 \mathrm{mbsf}$ to $-60.1 \%$ at $102.17 \mathrm{mbsf}$ and $-62.1 \%$ at $164.98 \mathrm{mbsf}$. These results fall within a similar range to values found in methane of natural gas hydrates and hydrate-containing sediments sampled offshore Northern California, Eel River Basin (Brooks et al., 1991) and offshore Peru, Peru-Chile Trench, ODP Leg 112 (Kvenvolden and Kastner, 1990). The values indicate a methane generated microbially (bacterial or autochthonous 
A

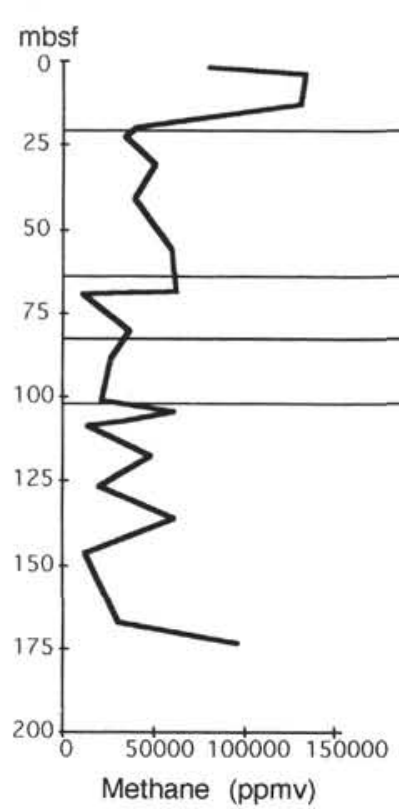

Headspace, 892A

B
C
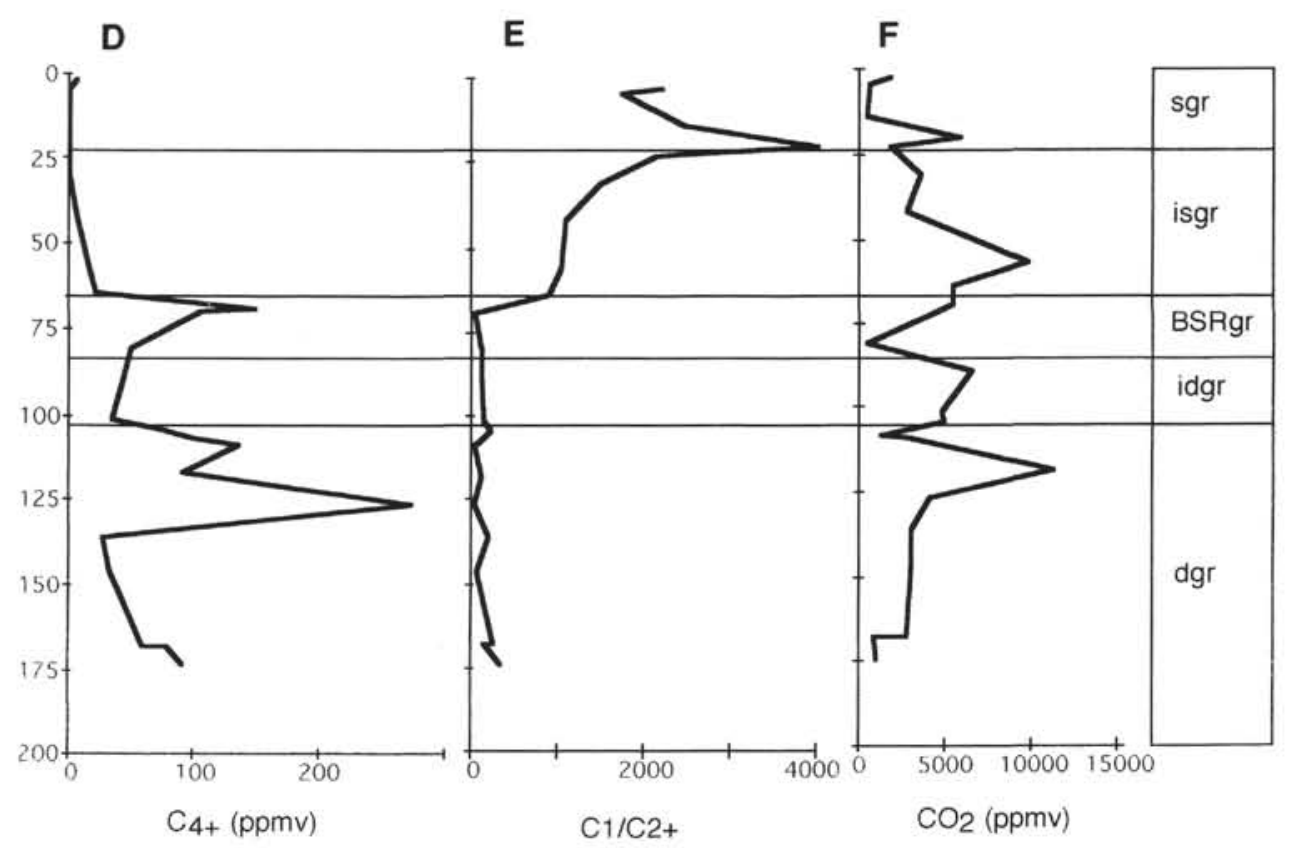

Figure 3. A-D, F. Concentration plots for headspace gases. E. Gas "wetness ratio" (i.e., the ratio between the methane concentration and the sum of gases heavier than ethane, inclusive). Abbreviations are as for Figure 2.

methane) in the shallow gas layer, and bacterial methane mixed with methane generated thermally (thermogenic or allochthonous methane) at depths greater than about $68 \mathrm{mbsf}$ (Fig. 2E).

\section{Higher Molecule Hydrocarbon Values}

Within the near-surface sediment zone containing high $\mathrm{H}_{2} \mathrm{~S}$ and $\mathrm{CH}_{4}$ concentrations, the headspace ethane concentration reaches a local maximum value of $77 \mathrm{ppmv}$ at $3.67 \mathrm{mbsf}$ and decreases to a minimum value of $10 \mathrm{ppmv}$ at $19.03 \mathrm{mbsf}$ (Fig. 3B). A seven-fold concentration increase then occurs above and at the BSR, from a depth of 62.48 (41 ppmv) to $67.53 \mathrm{mbsf}$ ( $281 \mathrm{ppmv}$ ), which remains more or less constant to 79.63 mbsf. In the corresponding EVG pro- file (Fig. 2E), there is a local ethane maximum of $6322 \mathrm{ppmv}$ below the BSR at $81.26 \mathrm{mbsf}$. These trends indicate a significant change in gas composition of both EVG and headspace gases near the BSR (located at $73.9 \mathrm{mbsf}$ ) that is sustained to about $100 \mathrm{mbsf}$. At this depth ( $100.99 \mathrm{mbsf}$ ) there is a distinct local minimum in headspace ethane concentration of $121 \mathrm{ppmv}$. At a general depth of $125 \mathrm{mbsf}$ there is another local maximum in headspace ethane concentrations of 525 ppmv, which corresponds to an EVG ethane maximum (Fig. 2B).

Except for iso-pentane $\left(i-\mathrm{C}_{5} \mathrm{H}_{12}\right)$ and normal-hexane $\left(n-\mathrm{C}_{6} \mathrm{H}_{14}\right)$, no other higher-than-ethane $\left(\mathrm{C}_{2+}\right)$ headspace hydrocarbons were detected down to a depth of $40.48 \mathrm{mbsf}$ (Westbrook, Carson, Musgrave, et al., 1994). At a depth of only $1.51 \mathrm{mbsf}$ both these gases occurred in small, but significant quantities (1.4 and $3.6 \mathrm{ppmv}$, respectively). 
As for ethane (Fig. 3B), the absolute highest headspace concentrations for propane, butane, $i$-pentane, and $i$-hexane occur at about 125 mbsf.

The ratio between headspace methane and the sum of higher-thanethane headspace hydrocarbons $\left(C_{1} / C_{2+}\right)$ is a parameter termed the "wetness indicator," used to judge the amount of thermogenically produced hydrocarbons existing in the sediments. Whereas the bulk of methane contained in marine sediments is normally assumed to be generated microbially from organic matter within the sediments (Claypool and Kaplan, 1974), the higher hydrocarbons ethane-hexane are considered to be of thermogenic (high-temperature) origin (Hunt, 1979). The $\mathrm{C}_{1} / \mathrm{C}_{2+}$ profile for headspace gases for Hole $892 \mathrm{~A}$ shows that the gas is primarily biogenic to a depth of $62.48 \mathrm{mbsf}$, and that it is primarily thermogenic from $67.53 \mathrm{mbsf}$ to the bottom of the hole. The lowest ratios are found at $68.17,106.73$, and 125.92 mbsf. At these three particular depths there is a combination of low headspace methane concentrations with high or relatively high ethane, propane, butane, pentane, and hexane concentrations. Stable isotope values support these findings (Fig. 2E).

\section{SEDIMENT GAS REGIMES IN HOLE 892A}

Based on the above descriptions and discussions it is possible to divide the sediment column of Hole $892 \mathrm{~A}$ into five gas regimes:

1. The "shallow gas regime" ("sgr" in Figs. 2 and 3) characterized by high methane concentrations, high hydrogen sulfide concentrations, low carbon dioxide concentrations, and a little ethane; its depth interval is from surface ( $1.51 \mathrm{mbsf})$ to about 20 mbsf (i.e., at least $15.15 \mathrm{mbsf}$ ).

2. The "intermediate shallow gas regime" ("isgr" in Figs. 2 and 3) characterized by moderate methane concentrations, relatively high carbon dioxide concentrations, moderate to low hydrogen sulfide concentrations, low ethane to hexane concentrations; the depth interval is from 15.15 to about 62.48 mbsf.

3. The "BSR gas regime" ("BSRgr" in Figs. 2 and 3) characterized by an abrupt decrease in headspace methane concentrations, relatively low carbon dioxide concentrations, locally peaking and relatively high ethane to hexane concentrations, and transition to sediments without hydrogen sulfide. The depth interval is from 62.48 to 79.63 mbsf, with the most dramatic organic geochemical gradient zone occurring between 67.53 and 68.17 mbsf. The depth 68 mbsf may therefore be termed "the geochemical BSR," even though it is located up to $6 \mathrm{~m}$ above the "true" BSR, as determined by geophysical methods (MacKay et al., 1994).

4. The "intermediate deep gas regime" ("idgr" in Figs. 2 and 3) characterized by low methane concentrations, moderate ethane, higher hydrocarbon, and carbon dioxide concentrations. The depth interval is from 79.63 to 100.99 mbsf.

5. The "deep gas regime" ("dgr" in Figs. 2 and 3) characterized by low to moderate methane concentrations, locally peaking and high ethane, higher hydrocarbon, and carbon dioxide concentrations. The depth interval is from 100.99 to $173.10 \mathrm{mbsf}$. There is a consistent peak of higher hydrocarbons at 125.92 mbsf, where the methane concentration is low.

This division helps us to discuss possible connections between the geophysical BSR boundary and the sediment gas distribution. Since the BSR lies somewhere between the depths bounding the "BSR gas regime" (i.e., between 62.48 and $79.63 \mathrm{mbsf}$ ) the answer to any questions concerning the relationship between free gas and the BSR should be found here. However, whereas there are five headspace gas observations within this regime, there is only one EVG observation (at $63.85 \mathrm{mbsf}$ ). The reason for this undersampling with respect to EVG is that only one expansion void was found in the sediments sampled in this depth interval.

Special awareness about gas amounts and composition was part of the safety precautions while drilling into the BSR zones on Leg 146. The fact that no significant release of gas occurred during the BSR penetration is an important observation in itself. This, in addition to the low amounts of headspace gas observed and the very low number of EVG observations at and immediately below the BSR, indicates that there does not necessarily exist a large gas reservoir beneath even such a prominent BSR as the one penetrated at Site 892 . Relatively high concentrations of higher hydrocarbons were, however, detected within the "BSR gas regime," which proves that allochthonous gases exist in this zone within the pore water and formation water systems and possibly in disseminated gas hydrates.

The paradox that geophysical observations require the presence of gas beneath the BSR has, however, to be addressed and explained. The VSP and seismic observations indicate acoustically significant amounts of gases in the zone immediately beneath the BSR. By volume, an "acoustically significant" amount of free gas is in the range $1 \%-5 \%$ by volume, according to Singh et al. (1993). Physicochemically, this requires that the pore water and the formation water systems are saturated with gas molecules. The only gas species showing a concentration increase in the "intermediate deep gas regime," directly underlying the BSR, is headspace carbon dioxide (Fig. 3F); all other gas species have a decreasing or constant trend with depth in this zone.

A scenario that possibly could explain this paradox would be the existence of a combination of (1) a minutely fractured reservoir beneath the BSR, where the fractures are filled with free gas (maximum $1 \%-5 \%$ free gas by volume); and (2) a very compacted and/or waterdepleted sediment beneath the BSR. This second requirement would account for the low gas concentration values found in the headspace readings - even if the pore water and formation water systems were saturated with gas (perhaps mostly $\mathrm{CO}_{2}$ ). Because of consolidation, the sediment water amounts would then be anomalously low, and therefore the headspace gas concentration values would be equally low. The sediment water content values from the hole (Westbrook, Carson, Musgrave, et al., 1994) indicate the presence of at least some anomalously low water content sediments immediately beneath the BSR, but the values are ambiguous. However, a particularly waterdepleted sediment sample was found at $115 \mathrm{mbsf}$ (i.e., about $45 \mathrm{~m}$ below the BSR). This was noted by chance, during routine sediment sub-sampling for headspace gas analysis, when highly consolidated sediment (clay) particles or chips were noticed to be so dry that, because of electrostatic forces, they stuck to the inner walls of the glass sampling vial. Subsequent measurements determined the water content to be only $14 \%$ (dry weight) in this sub-sample.

To simplify the discussion, it is possible to divide the gas profiles into only two main "pools" of sediment gas, delineated by the 68 mbsf level: the upper pool (combining the two upper gas regimes with the upper part of the "BSR gas regime") and the lower pool (combining the two lower regimes with the lower part of the "BSR gas regime"). In the upper pool, methane and hydrogen sulfide dominate over the other gases. In the lower pool, headspace methane concentrations are moderate to low, whereas the higher hydrocarbon concentrations (ethane to hexane) are high. Although headspace carbon dioxide peaks to high levels in both pools, it achieves its highest concentration in the lower pool.

The reason for the dramatic gas concentration and composition change at the 68 mbsf-level may be because of one or a combination 
of several factors. At this stage we will consider and discuss three possible factors:

1. Change in sediment type;

2. Reactions caused by gas hydrates; and

3. Flow through tectonically produced conduits.

The "upper gas pool", as defined above, is fully located within lithostratigraphic Subunit IA, which is bounded by an inferred shear zone at 68 mbsf. The "lower gas pool" occupies lithostratigraphic Subunit IB, which extends to the bottom of the hole. Whereas the sediments at Site 892 mainly consist of terrigenous silty clay and clayey silts with sporadic sand layers, Subunit IA is richer in sand than the deeper section of the hole. The sand layers consist of authigenic glauconite pellets with biogenic silica. Subunit IB exhibits more fracturing and stratal disruption than Subunit IA. This one-to-one correlation between the two gas pools and the stratigraphic units certainly suggests that the sediment gas composition is related to the sediment types. For example, it may be envisaged that the higher sand content in Subunit IA favors accumulation and perhaps generation of methane in this unit, because the carbon isotope composition of methane suggests there to be at least two sources of methane: autochthonous microbially produced, and migrated thermogenically sourced, that mixes with the microbial gas. Alternatively, the high methane content might result from dissolution of gas hydrate that are expected to form and be stable above the BSR.

Formation of gas hydrate may influence gas composition and concentrations. If the sediment column at Hole $892 \mathrm{~A}$ is imagined to have started out with a uniform distribution of sediment gases (i.e., a constant gas concentration and composition with depth), then, after a pressure and temperature change to the current conditions, gas hydrates would start forming. Where hydrodynamically and thermodynamically possible, available pore water would combine with gas molecules to form gas hydrates within the sediment column. Current theory for natural gas hydrates states that a continuous supply of gas molecules is necessary to maintain the gas hydrates and to prevent them from dissociating (Hyndman and Davis, 1992; Soloviev and Ginsburg, 1994). Although the composition of such a gas flow is unknown, it must be assumed that the flow contains mainly methane, with small amounts of higher hydrocarbons (i.e., similar to the gas composition currently found in the "lower gas pool"). It is thus suspected that the gas composition as determined by our EVG and headspace methods, in the "upper gas pool" has become significantly altered because of gas hydrate formation within this zone. It thus seems that the formation and presence of gas hydrate either stimulates methane generation, or partly prevents the heavy hydrocarbons from migrating. It is reasonable to suspect that both mechanisms are active, a result indicating that actively forming gas hydrates may act as a boost to vertical methane migration, generation, and accumulation, but also as a filter or a "cap" to vertical migration of higher hydrocarbons.

At Site 892 , porous, fractured zones, caused by tectonic activity such as shear-faulting, are suspected to occur at 68 and 116 mbsf. Furthermore, these zones are suspected to serve as active fluid flow conduits (Westbrook, Carson, Musgrave, et al., 1994). It is reasonable to suspect that these two conduits will act as effective drainage pathways for some of the gases within Subunit IB (the "lower gas pool"). If this is the case, it is suggested that higher hydrocarbons originating deeper than Subunit IB are effectively being transported through the conduits, bypassing Subunit IA at Site 892 , and thereby partly preventing them from entering into the sediments of Subunit IA.The presence of some thermogenic methane and ethane in the "upper gas pool" can be explained as a result of migration through sediments and gas hydrate uptake in this shallow gas regime.

\section{GAS HYDRATES IN HOLE 892A}

On ODP Leg 146, solid gas hydrates were directly observed only at Site 892. In Hole 892A they were sampled at $3.7 \mathrm{mbsf}$, where they occurred as clear (colorless) nodules, $2-3 \mathrm{~cm}$ long and $1 \mathrm{~cm}$ wide. The nodules were in pelletoidal form, resembling white hailstones of 4-5 mm diameter, embedded in the soft clay sediment (Fig. 4; Westbrook, Carson, Musgrave, et al., 1994). The "pellets" were evenly distributed in the sediment matrix, with a spacing of about $50-60 \mathrm{~mm}$ between each gas hydrate pellet (Fig. 4). Indirect evidence of the in situ occurrence of gas hydrates at depths below 19 mbsf was also found, but only to a depth of about $68 \mathrm{mbsf}$. This indirect evidence is in the form of chloride depletions and anomalously low core temperatures, measured immediately after core retrieval. It is inferred that the low temperatures were caused by exothermal processes during gas hydrate dissociation. In Hole 892A, the deepest of these temperature anomalies was measured at $67.5 \mathrm{mbsf}$ (Westbrook, Carson, Musgrave, et al.,1994, p. 342), where a $2{ }^{\circ} \mathrm{C}$ cooling occurred. The deepest strong chlorinity minimum ( $15 \%$ less than normal seawater) was found at $68 \mathrm{mbsf}$, associated with a "soupy" layer (Westbrook,
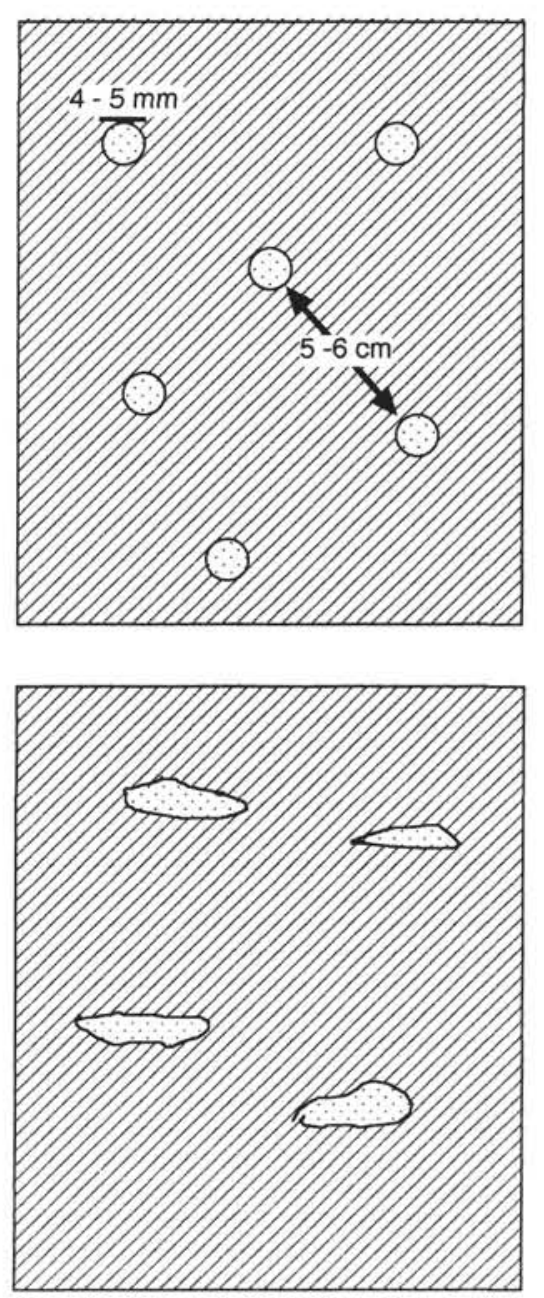

Figure 4. Sketch showing an impression of how the solid gas hydrates were found in the upper portion of the soft sediments in Hole 892A. The "pellets" (upper figure) resemble white hailstones in a soft clay matrix. The irregular nodules (lower figure) were colorless to white (same scale). 
Carson, Musgrave, et al., 1994, p. 345). Considering that these two indicators are totally independent of each other, they agree very well, suggesting the occurrence of in situ gas hydrates at about $68 \mathrm{mbsf}$, which has previously been called "the geochemical BSR".

\section{Theoretical Hydrate Equilibrium}

Although sparse, the observed free gas composition in Hole $892 \mathrm{~A}$, together with downhole Water-sampling Temperature Profile (WSTP) temperature and interstitial-water salinity measurements made in the same hole, provide us with a unique set of data, upon which to calculate theoretical hydrate equilibrium temperatures in the hole. This has been done in Figure 5, using the commercially available computer program "HYD FLS" (version 1.00, CALSEP A/S, Denmark) which is widely used in the hydrocarbon industry. The free gas (EVG) composition has been taken from table 8 (Westbrook, Carson, Musgrave, et al., 1994, p. 335) and the interstitial water salinity from table 11 (Westbrook, Carson, Musgrave, et al., 1994, p. 343). The geothermal gradient as determined by WSTP measurements in Hole 892A (Westbrook, Carson, Musgrave, et al., 1994, p. 355 , table 19) is shown as the broken line in Figure 5. From these calculations, gas hydrates can theoretically only be stable at depths ranging from the seafloor down to approximately $45 \mathrm{mbsf}$.

The stability of the hydrate is particularly strong between the seafloor and 15.15 mbsf, because of the stabilizing effect of high $\mathrm{H}_{2} \mathrm{~S}$ concentrations. There is a dramatic stability decrease from 15.15 to $21.71 \mathrm{mbsf}$. This correlates well with the gas hydrate observations and the evidence of anomalously high water contents (Westbrook, Carson, Musgrave, et al., 1994). However, newly established data on long-term observations of temperature in Hole 892B (Davis et al., in press), indicate a $0.7^{\circ} \mathrm{C}$ lower geothermal temperature at $78 \mathrm{mbsf}$, than the one shown in Figure 5, which brings the observed geothermal temperature at this depth very close to the theoretical hydrate equilibrium temperature. This suggests that there may be pockets or layers of stable gas hydrates down to this depth, at least in Hole 892B, which is located about $200 \mathrm{~m}$ from Hole $892 \mathrm{~A}$. However, it may be concluded from these calculations and measurements in Hole 892A, that there are at least two independent indicators of in situ stable gas hydrates to a depth of about $68 \mathrm{mbsf}$. These are anomalously low temperatures in opened cores, "soupy" layers, and depleted interstitial water chlorinity. In the sediments located between 45 and 68 mbsf, there is also a "soupy" layer of low chlorinity (of 11\%) at 56 mbsf. This indicates the possibility of in situ gas hydrates in Hole $892 \mathrm{~A}$ deeper than $45 \mathrm{mbsf}$, but only in very distinct layers but not deeper than 68 mbsf.

A peculiarity shown on Figure 5 is that it is theoretically possible to form gas hydrates at a depth of 116.84 mbsf because of the high propane content at this level. According to Figure 5, the BSR at 73.9 mbsf (MacKay et al., 1994), must therefore have other explanations than being the base of currently stable gas hydrates.

\section{Gases From Dissociating Gas Hydrates}

Two different gas hydrate gas extraction experiments were run on board ship: (1) Immediately after sediment sampling from the opened cores on deck, sediments containing abundant gas hydrate pellets were put into plastic $100 \mathrm{~cm}^{3}$ syringes (Syringes $1-4$, see Table 1). (2) A further set of sediments containing gas hydrate pellets and nodules were put in sealed plastic bags, for four days of storage in liquid $\mathrm{N}_{2}$. In experiment 1 , above, Syringe 1 (estimated to contain $10 \%$ air, $40 \%$ pure hydrate, and $50 \%$ soft clay sediment) was observed, while rapid gas hydrate dissociation took place over a period of only $4 \mathrm{~min}$. The volume increase was measured by observing the plunger displacement as a function of time. Results are provided in Table 1B and Figure 6. To extract gas at various stages during dissociation and melting, the following method was used (Fig. 7): The $100 \mathrm{~cm}^{3}$ syringe needle was pushed halfway into the rubber stopper of pre-evacuated Vacutainers ${ }^{\mathrm{TM}}$, the stopper acting as an effective seal for the dissociating gas hydrates in the syringe. A gas sample was taken every time the syringe needle was pushed through this stopper, exposing the syringe volume to the vacuum of the Vacutainer ${ }^{\mathrm{TM}}$.

In experiment 2 , the frozen sediments were put into plastic 100 $\mathrm{cm}^{3}$ syringes (Syringes 5-7, see Table 2) for thawing and gas analysis. As the sediments partly thawed, the plunger was compressed to drive out excess air. A total of six gas samples from the three syringes were acquired. The two gas samples acquired from each of the three syringes were taken after partial thawing of the samples. This occurred 2-3 hr after the samples had been transferred from the liquid

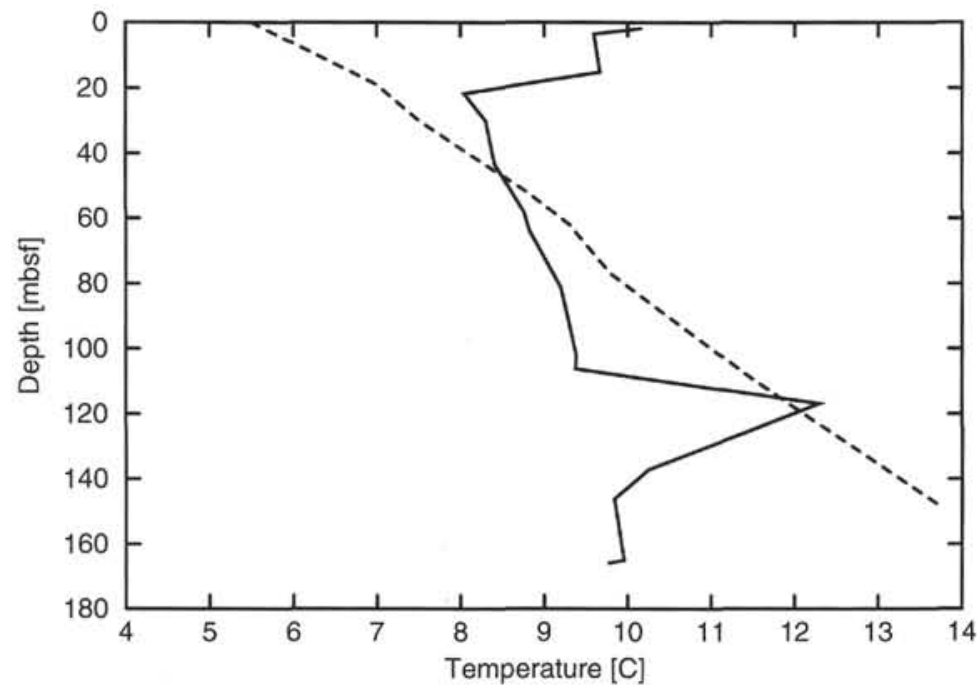

- Hydrate equilibrium

-..- Geothermal gradient
Figure 5. A plot showing the calculated hydrate equilibrium temperature of Hole 892A, based on EVG (free) gas composition and the measured interstitial-water salinities (Westbrook, Carson, Musgrave, et al., 1994). The broken curve shows the geothermal gradient measured in situ with the water-sampling temperature profile (WSTP), for comparison. According to these two curves, gas hydrates in Hole $892 \mathrm{~A}$ can be stable only down to about $45 \mathrm{mbsf}$ and in a small zone at about 116 mbsf (because of a locally high propane value). The hydrate equilibrium temperature curve is calculated using the commercially available program "HYD FLS" (version 1.00, CALSEP A/S, Denmark). 
Table 1. A. Hydrocarbons in fresh gas hydrate-containing sediments at 3.7 mbsf, Hole 892A.

\begin{tabular}{cccccccccc}
\hline Syr & Methane Ethane & Propane & Butane & $\mathrm{CO}_{2}$ & $\mathrm{H}_{2} \mathrm{~S}$ & $\mathrm{C}_{5+}$ & $\begin{array}{c}\text { Volume } \\
\text { of air and } \\
\text { sample }\end{array}$ \\
\hline 1 & 66,408 & 30 & 1.4 & 21.2 & 504 & 11,733 & 4.0 & $38 \mathrm{~cm}^{3}$ \\
2 & 10,210 & 8 & 1.5 & 31.5 & 711 & 12,280 & $\mathrm{ND}$ & $26 \mathrm{~cm}^{3}$ \\
3 & 36,026 & 12 & ND & ND & 274 & ND & ND & $10 \mathrm{~cm}^{3}$ \\
4 & 46,085 & 22 & 1.5 & 31.0 & 731 & 12,408 & $\mathrm{ND}$ & $45 \mathrm{~cm}^{3}$ \\
Avg. & 39,682 & 18 & 1.5 & 27.9 & 555 & 12,140 & 4.0 & $30 \mathrm{~cm}^{3}$ \\
\hline
\end{tabular}

Notes: $\mathrm{Syr}=$ syringe. All values are ppmv. The gas samples were obtained after most of the visible gas hydrates had disseminated (i.e., after about $4 \mathrm{~min}$, or 240 s).

B. Volume expansion observed in Syringe 1.

\begin{tabular}{crc}
\hline Syr & Time $(\mathrm{s})$ & $\begin{array}{c}\text { Volume } \\
\left(\mathrm{cm}^{3}\right)\end{array}$ \\
\hline 1 & 1 & 27.5 \\
1 & 10 & 30.0 \\
1 & 50 & 33.9 \\
1 & 240 & 38.5 \\
\hline
\end{tabular}

Note: see also Figure 6.

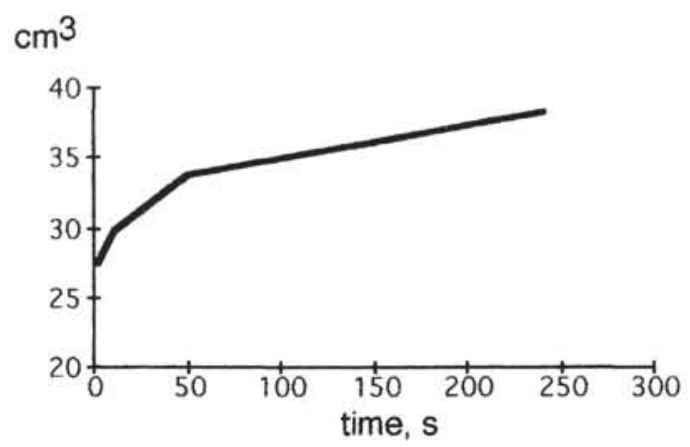

Figure 6. Results from observation of expansion because of dissociating gas hydrates in Syringe 1. The volumes are estimates based on the distance traveled by the syringe plunger (see Fig. 7 and text).

nitrogen storage to the syringes. It also was estimated here that about $40 \%$ of the sediment/gas hydrate mixture consisted of pure natural gas hydrates.

Whereas the gases from Experiment 1 (Syringes 1-4) were analyzed on board, the gases from Experiment 2 (Syringes 5-7) were stored for several months in the Vacutainers ${ }^{\mathrm{TM}}$ before analysis at Geolab Nor's onshore geochemical laboratory in Norway. The results from these gas samples are listed in Table 2. Each sample is identified with syringe number and the time after transfer from liquid nitrogen storage to the pre-evacuated glass tubes. After $2 \mathrm{hr}$ and 10 $\mathrm{min}$ and $2 \mathrm{hr}$ and $50 \mathrm{~min}$ the samples were only partly melted. After $3 \mathrm{hr}$ and $18 \mathrm{~min}$ the bulk of the sediments had melted and most of the gas hydrate "pellets" and nodules had dissociated into water and gas.

Comparing these gas compositions with those at corresponding depths in the EVG and Headspace gases, we see a major difference: the gases sampled from the gas hydrate-containing sediments contain abundant high-molecule-hydrocarbons. Only the gas sample from Syringe 6, taken at $2 \mathrm{hr} 10 \mathrm{~min}$ (Table 2), shows no $\mathrm{C}_{3+}$ components. However, the sample taken about one hour later, from the same syringe (Syringe 6, at $3 \mathrm{hr} 18 \mathrm{~min}$, Table 2), contains also the higher hydrocarbons: propane, butane, pentane, propene, butene, $i$-butane, and
Table 2. Hydrocarbons in frozen gas hydrate-containing sediments at 3.7 mbsf, Hole 892A.

\begin{tabular}{ccrrccc}
\hline Syr & Sample & Methane & Ethane & Propane & Butane & $\mathrm{C}_{5+}$ \\
\hline 5 & 2h $50 \mathrm{~m}$ & 31,480 & 31.79 & 0.68 & 1.30 & 1.92 \\
5 & 3h $18 \mathrm{~m}$ & 427 & 2.18 & 0.48 & 0.89 & 1.55 \\
6 & 2h $10 \mathrm{~m}$ & 19,049 & 169.87 & $\mathrm{ND}$ & $\mathrm{ND}$ & $\mathrm{ND}$ \\
6 & 3h $18 \mathrm{~m}$ & 289 & 0.62 & 0.09 & 0.33 & 0.34 \\
7 & 2h $50 \mathrm{~m}$ & 3,539 & 7.34 & 0.76 & 1.50 & 2.01 \\
7 & 3h 18m & 272 & 0.53 & 0.14 & 0.56 & 0.44 \\
Avg. & 2h xm & 14,689 & 69.67 & 0.48 & 0.94 & 1.30 \\
Avg. & 3h $18 \mathrm{~m}$ & 369 & 1.11 & 0.24 & 0.55 & 0.81 \\
\hline
\end{tabular}

Notes: Syr $=$ syringe; $x m=10$ or $50 \mathrm{~min}$. "Sample" shows the time at which the gas sample was acquired, after it had been taken out of liquid nitrogen storage. All values are ppmv.

$i$-pentane. This strongly suggests that the higher hydrocarbons (except for the pentanes) were contained in the disseminated gas hydrate "pellets" and nodules. The occurrence of the pentanes can, however, only be explained as molecules that have migrated directly to the shallow zone in the gas or water phase (Table 2).

Another difference is also evident. Whereas there was very little $\mathrm{CO}_{2}$ compared to methane in the headspace and EVG analyses in the near surface, there is relatively high concentrations of $\mathrm{CO}_{2}$ in the gas hydrate containing sediments (Table 3 ). At $3 \mathrm{hr} 18 \mathrm{~min}, \mathrm{CO}_{2}$ actually dominates the other gases in two out of three samples. Although the reason for this could be oxidation of the hydrocarbons in the presence of low-chlorinity water from the rapidly dissociating gas hydrates, it is most probable that $\mathrm{CO}_{2}$ was also contained in the gas hydrates.

A few other interesting results are also noted:

1. The methane and ethane gas concentrations are dramatically reduced in the second sample of each syringe (Table 2), indicating that the gases methane and ethane either dissociate early (at low temperature), or that they are mainly contained in the pore water of the sediments.

2. The $\mathrm{C}_{2+}$ hydrocarbon gas concentrations are only slightly to moderately reduced in the second sample of Syringes 5 and 7 , indicating that the heavy gases dissociate over a wide range of temperatures (Table 2).

3. Except for in one sample, the $\mathrm{CO}_{2}$ concentration increases dramatically in the second sample (Table 3).

4. The $\mathrm{H}_{2} \mathrm{~S}$ concentrations increase in two out of three samples, indicating that $\mathrm{H}_{2} \mathrm{~S}$ is a "conservative" gas, dissociating at high temperatures.

5. The isotopic ratio for methane becomes consistently lighter in the second sample, indicating that the carbon isotope ${ }^{13} \mathrm{C}$ may dissociate faster than ${ }^{12} \mathrm{C}$ (Table 3 ).

6. The isotopic ratio for methane in the first sample is similar to the EVG methane sample for the corresponding depth, indicating that the methane sampled from the core liner in an expansion void had been dissociated from gas hydrate.

If we average the results from the three syringes they indicate that the second samples from each syringe may reflect the gas composition contained in the gas hydrate "pellets" in experiment 1 (Table 1A; Fig. 8). The most surprising result, therefore, is that so much of this final gas mixture is $\mathrm{CO}_{2}$ and $\mathrm{H}_{2} \mathrm{~S}$ (Fig. 8). This $\mathrm{CO}_{2}$ most probably is the result of release from dissociating gas hydrates, and therefore may represent the main source of the gas observed seeping through the sea floor near Sites 891 and 892 by Suess and Whiticar (1989).

\section{Comparison with Other Natural Gas-hydrate Gases}

In the literature, there are a number of published gas compositions derived either from sediments containing gas hydrates, "pure" natural 


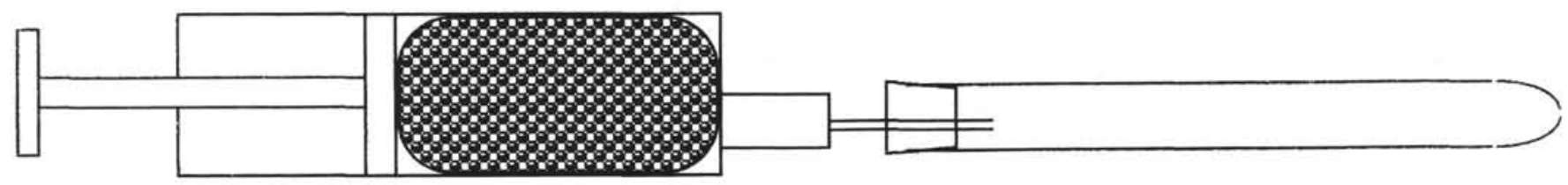

Figure 7. Sketch showing observation and sampling method for sediments containing dissociating gas hydrates. The large syringe on the left is a $100-\mathrm{cm}^{3}$ volume syringe.

gas hydrates (only containing very little sediment), and bubbles emanating from dissociating gas hydrates on the sea floor (Anderson et al., 1992; MacDonald et al.,1994; Soloviev and Ginsburg, 1994). When we compare the compositions observed in our gas hydrate experiments 1 and 2 (Tables $1-3$; Fig. 8 ), we find that there are no other reports of high $\mathrm{H}_{2} \mathrm{~S}$ percentages in such gases. When comparing these gases with others we must therefore do it on the basis of hydrocarbon and $\mathrm{CO}_{2}$ contents. In Figure 8 the gases observed in our two experiments are displayed as percentages of total sum of hydrocarbon gases methane $\left(\mathrm{C}_{1}\right)$ to pentane $\left(\mathrm{C}_{5}\right), \mathrm{H}_{2} \mathrm{~S}$, and $\mathrm{CO}_{2}$. In Figure 9 these gas compositions have been recalculated as percentages of hydrocarbons and $\mathrm{CO}_{2}$ for comparison with gas hydrate-associated gases published elsewhere. It may be noted that the gas composition with the greatest resemblance is from Mississippi Canyon, Gulf of Mexico (Anderson et al., 1992).

\section{MAIN CONCLUSIONS}

Based on organic geochemical analyses, Hole $892 \mathrm{~A}$ may be divided into five gas regimes with the following characteristics:

1. The "shallow gas regime" (0-15 mbsf) characterized by high methane concentrations, high hydrogen sulfide concentrations, low carbon dioxide concentrations, and a little ethane.

2. The "intermediate shallow gas regime" (15-62.5 mbsf) characterized by moderate methane concentrations, relatively high carbon dioxide concentrations, moderate to low hydrogen sulfide concentrations, and low ethane to hexane concentrations.

3. The "BSR gas regime" (62.5-79.6 mbsf) characterized by an abrupt decrease in headspace methane concentrations, relatively low carbon dioxide concentrations, locally peaking and relatively high ethane to hexane concentrations, and transition to sediments without hydrogen sulfide. The most dramatic organic geochemical gradient zone occurs at about $68 \mathrm{mbsf}$. This depth is therefore termed "the geochemical BSR," even though it is located up to 6 meters above the "true" BSR, as determined by geophysical methods (MacKay et al., 1994).

4. The "intermediate deep gas regime" (79.6-101 mbsf) characterized by low methane concentrations, moderate ethane, higher hydrocarbon, and carbon dioxide concentrations.

5. The "deep gas regime" (101-173 mbsf) characterized by low to moderate methane concentrations, locally peaking and high ethane, higher hydrocarbon, and carbon dioxide concentrations. There is a consistent peak of higher hydrocarbons at $125.92 \mathrm{mbsf}$, where the methane concentration is low.

These regimes belong to two main gas pools, delimited by "the geochemical BSR" at 68 mbsf: the upper gas pool and the lower gas pool. In the upper pool, methane and hydrogen sulfide dominate over the other gases, and the stable isotope signature indicates the methane to be mainly of a microbial origin. In the lower pool, headspace methane concentrations are moderate to low, whereas the higher hydrocarbon concentrations (ethane to hexane) are high, signifying influx of thermogenic gases.

Shallow sediments with dissociating gas hydrate "pellets" and nodules have a gas composition consisting of methane, $\mathrm{H}_{2} \mathrm{~S}, \mathrm{CO}_{2}$, bu- tane, ethane, propane, propene, butene, and i-butane (in decreasing order of concentrations). It is believed that most of these gases, except an unknown proportion of the methane, originate from the dissociated gas hydrates. A comparison with results from other areas with sediments containing dissociating natural gas hydrates, shows that the gas composition found at Site 892A is similar, apart from the $\mathrm{H}_{2} \mathrm{~S}$ component. It is the first time large amounts of gas hydratebound $\mathrm{H}_{2} \mathrm{~S}$ has been reported from a marine environment.

Theoretical hydrate equilibrium temperature calculations, based on the observed free gas composition and interstitial water salinities of Hole 892A, provides a somewhat surprising result when compared with measured geothermal values in the hole:

1. Hydrates are stable down to a depth of only approximately 45 mbsf.

2. They are very stable down to $15 \mathrm{mbsf}$, but stability decreases dramatically down to 21.7 mbsf because of less $\mathrm{H}_{2} \mathrm{~S}$ in the gas mixture.

3. Below a depth of $45 \mathrm{mbsf}$ the hydrates are only intermittently or conditionally stable.

There is indirect evidence that small amounts of disseminated gas hydrates occur in Hole 892A within discrete layers to a depth of 68 mbsf, "the geochemical BSR". Theoretically, there is also a zone at $116.8 \mathrm{mbsf}$ where a high propane content makes it possible for gas hydrates to form. According to these results, the (geophysical) BSR at 73.9 mbsf (MacKay et al., 1994) does not correspond with the base of gas hydrate stability in Hole $892 \mathrm{~A}$, which is shallower. These results, therefore, do not support the widely held notion that the bottom-simulating reflector observed on numerous reflection seismic records directly corresponds with the base of gas hydrate stability. However, there is probably some other associated causative mechanism between the BSR and the formation and /or dissociation of gas hydrates.

\section{ACKNOWLEDGMENTS}

The management of Statoil and the Norwegian Research Foundation are thanked for supporting this work, which includes both fieldwork time and time for subsequent research.

\section{REFERENCES}

Anderson, A.L., Sloan, E.D., and Brooks, J., 1992. Gas hydrate recoveries in the Gulf of Mexico: what is the shallow water depth limit for hydrate occurrence? In Leverette, S.J. (Ed.), Geology, Earth Sciences and Environment. Proc.-Annu. Offshore Technol. Conf., 24:381-385.

Bangs, N.L.B., Westbrook, G.K., Ladd, J.W., and Buhl, P., 1990. Seismic velocities from the Barbados Ridge Complex: indicators of high pore fluid pressures in an accretionary complex. J. Geophys. Res., 95:87678782.

Brooks, J.M., Cox, H.B., Bryant, W.R., Kennicutt, M.C., II, Mann, R.G., and McDonald, T.J., 1986. Association of gas hydrates and oil seepage in the Gulf of Mexico. Org. Geochem., 10:221-234.

Brooks, J.M., Field, M.E., and Kennicutt, M.C., II, 1986. Observations of gas hydrates in marine sediments, offshore northern California. Mar. Geol. 96:103-108. 
Cheng, W.K., 1975. Consolidation of sand formation using Freon-11 hydrate [M.S. thesis]. Univ, of British Columbia, Vancouver.

Claypool, G.E., and Kaplan, I.R., 1974. The origin and distribution of methane in marine sediments. In Kaplan, I.R. (Ed.), Natural Gases in Marine Sediments: New York (Plenum), 99-139.

Dillon, W.P., and Paull, C.K., 1983. Marine gas hydrates, II: geophysical evidence. In Cox, J.L. (Ed.), Natural Gas Hydrates: Properties, Occurrences, and Recovery: London (Butterworths), 73-90.

Field, M.E., and Kvenvolden, K.A., 1985. Gas hydrates on the California continental margin. Geology, 13:517-520.

Ginsburg, G.D., Soloviev, V.A., Cranston, R.E., Lorenson, T.D., and Kvenvolden, K.A., 1993. Gas hydrates from the continental slope, offshore Sakhalin Island, Okhotsk Sea. Geo-Mar. Lett., 13:41-48.

Hunt, J.M., 1979. Petroleum Geochemistry and Geology: San Francisco (W.H. Freeman).

Hyndman, R.D., and Davis, E.E., 1992. A mechanism for the formation of methane hydrate and seafloor bottom-simulating reflectors by vertical fluid expulsion. J. Geophys. Res., 97:7025-7041.

Kvenvolden, K.A., 1993. Gas hydrates: geological perspective and global change. Rev. Geophys., 31:173-187.

Kvenvolden, K.A., and Barnard, L.A., 1983. Gas hydrates of the Blake Outer Ridge, Site 533, Deep Sea Drilling Project Leg 76. In Sheridan, R.E., Gradstein, F.M., et al., Init. Repts. DSDP, 76: Washington (U.S. Govt. Printing Office), 353-365.

Kvenvolden, K.A., and Kastner, M., 1990. Gas hydrates of the Peruvian outer continental margin. In Suess, E., von Huene, R., et al., Proc. ODP, Sci. Results, 112: College Station, TX (Ocean Drilling Program), $517-$ 526.

Lysne, D., 1995. Hydrate plug dissociation by pressure reduction [Ph.D.thesis]. Norwegian Institute of Technology, Trondheim.

MacDonald, I.R., Guinasso, N.L., Jr., Sassen, R., Brooks, J.M., Lee, L., and Scott, K.T., 1994. Gas hydrate that breaches the sea floor on the continental slope of the Gulf of Mexico. Geology, 22:699-702.
MacKay, M.E., Jarrard, R.D., Westbrook, G.K., Hyndman, R.D., and the ODP Leg 146 Scientific Party, 1994. Origin of bottom-simulating reflectors: Geophysical evidence from the Cascadia accretionary prism. Geology, 22:459-462.

Miller, J.J., von Huene, R., and Lee, M.W., 1991. An analysis of a seismic reflection from the base of a gas hydrate zone, offshore Peru. AAPG Bull., 75:910-924.

Minshull, T., and White, R., 1984. Plane-wave reflection coefficients for gas sands at non-normal angles of incidence. Geophysics, 49:1637-1648.

Ripmeester, J.A., Ratcliffe, C.I., and Klug, D.D., 1994. Molecular perspectives on structure and dynamics in clathrate hydrates. Proc. Int. Conf. Natural Gas Hydrates, Ann. N. Y. Acad. Sci., 715:161-176.

Singh, S.C., Minshull, T.A., and Spence, G.D., 1993. Velocity structure of a gas hydrate reflector. Science, 260:204-207.

Sloan, E.D., 1990. Clathrate Hydrates of Natural Gasses: New York (Marcel Dekker).

Soloviev, V., and Ginsburg, G.D., 1994. Formation of submarine gas hydrates. Bull. Geol. Soc. Den., 41:86-94.

Suess, E., and Whiticar, M.J., 1989. Methane-derived $\mathrm{CO}_{2}$ in pore fluids expelled from the Oregon subduction zone. Palaeogeogr., Palaeoclimatol., Palaeoecol., 71:119-136.

Trofimuk, A.A., Cherskiy, N.V., Makogon, Y.F., and Tsarev, V.P., 1972. Possible mechanism of the accumulation of natural gas. Int. Geol. Rev., 1968-1981, AGI Reprint Series, VI:72-76.

Westbrook, G.K., Carson, B., Musgrave, R.J., et al., 1994. Proc. ODP, Init. Repts., 146 (Pt. 1): College Station, TX (Ocean Drilling Program).

Date of initial receipt: 24 August 1994

Date of acceptance: 2 January 1995

Ms 146SR-210 a)

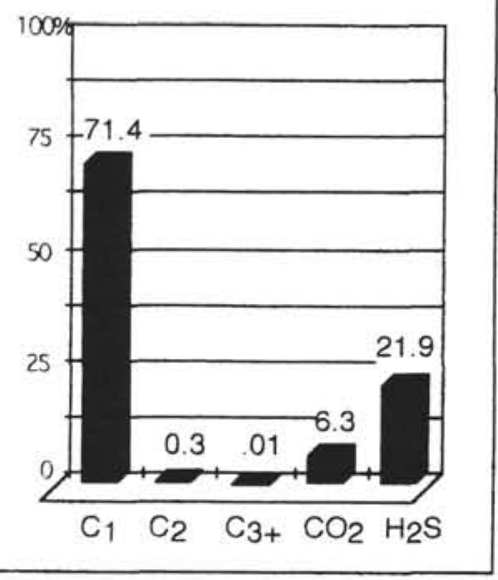

Avg. $2 \mathrm{~h} \times \mathrm{min} ., 892 \mathrm{~A}$ b)

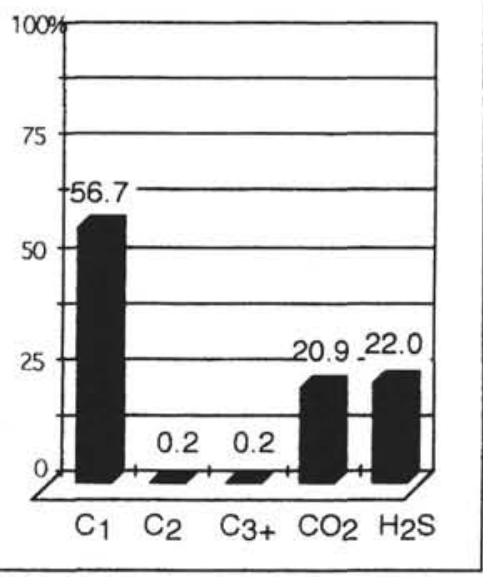

Avg.3h $18 \mathrm{~min} ., 892 \mathrm{~A}$ c)

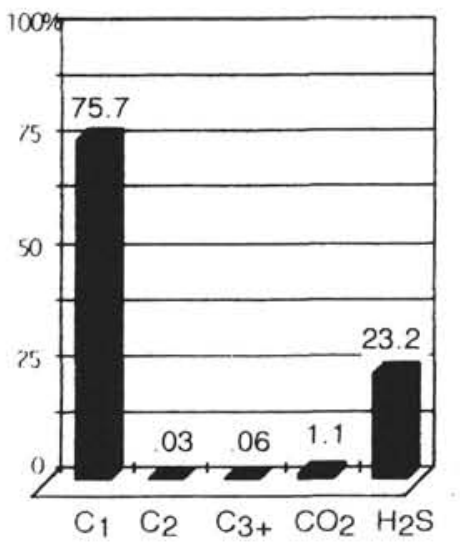

Avg. fresh sediment with gas hydrate pellets, $892 \mathrm{~A}$

Figure 8. Plots based on Tables 1, 2, and 3, showing percent average gas composition, from sediments containing dissociating gas hydrates. Note the high $\mathrm{H}_{2} \mathrm{~S}$ concentrations. 
Table 3. Methane, its isotopic ratio, $\mathrm{CO}_{2}$, and $\mathrm{H}_{2} \mathrm{~S}$ in gas hydrate-containing sediments at 3.7 mbsf, Hole $892 \mathrm{~A}$.

\begin{tabular}{rrrrrr}
\hline & & & & $\begin{array}{r}\text { Carbon } \\
\text { dioxide }\end{array}$ & $\begin{array}{c}\text { Hydrogen } \\
\text { sulfide } \\
\left(\mathrm{H}_{2} \mathrm{~S}\right)\end{array}$ \\
\hline 5 & 2h $50 \mathrm{~m}$ & 31,480 & -66.8 & $1,125.2$ & 88.46 \\
5 & 3h $18 \mathrm{~m}$ & 427 & -73.3 & 178.3 & 95.46 \\
6 & 2h $10 \mathrm{~m}$ & 19,049 & -65.4 & $1,639.3$ & 179.56 \\
6 & 3h $18 \mathrm{~m}$ & 289 & -67.5 & $7,502.5$ & 141.67 \\
7 & 2h $50 \mathrm{~m}$ & 3,539 & -69.0 & $1,126.5$ & 139.43 \\
7 & 3h $18 \mathrm{~m}$ & 272 & -75.8 & $5,822.4$ & 192.37 \\
\hline
\end{tabular}

Notes: $\mathrm{Syr}=$ syringe; isotopic values are given in \%o PDB; all other values are ppmv.

a)

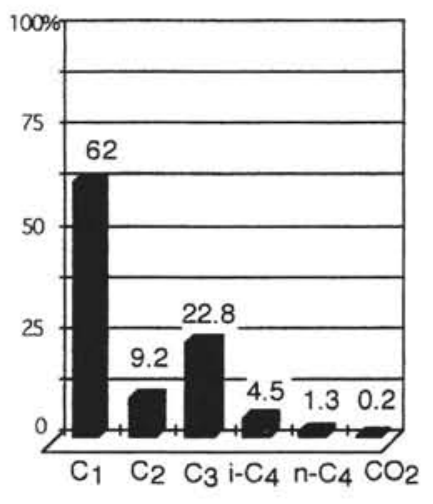

Green Canyon 204

\section{c)}

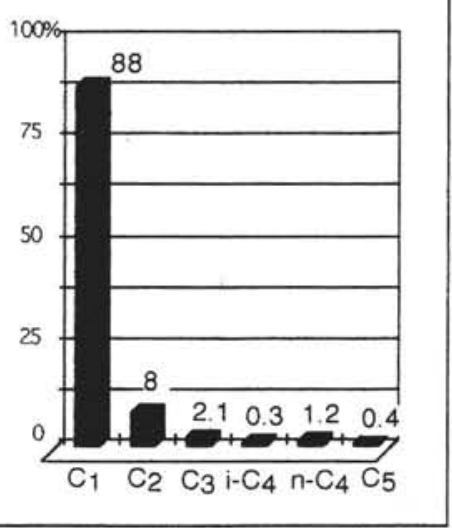

Bubbles, Bush Hill b)

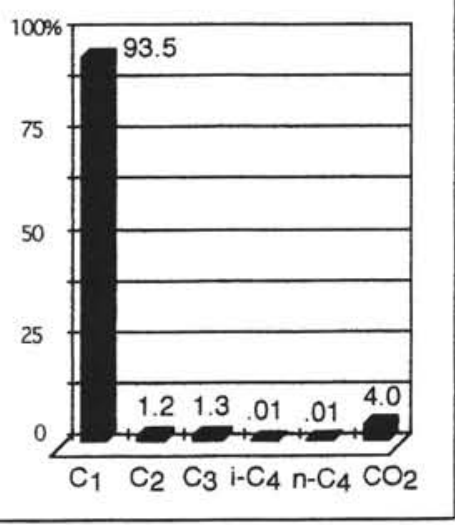

Mississippi Canyon

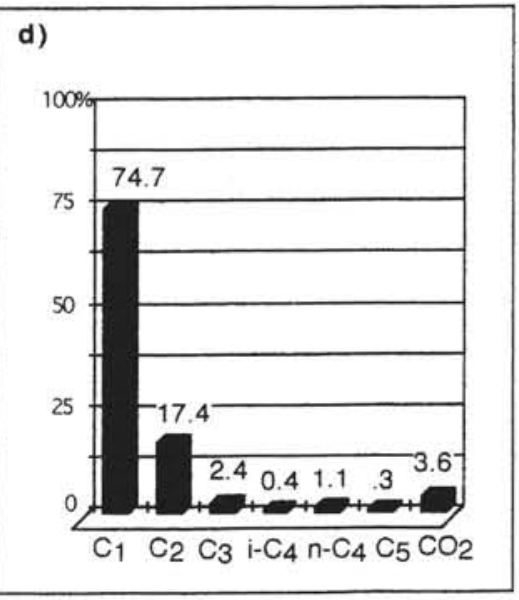

Buzdag

Figure 9. For comparison with Figure 8, plots of measured gas compositions from other published examples of dissociating natural gas hydrates. A, B. From the Gulf of Mexico (Anderson et al., 1992). C. From bubbles emanating from exposed gas hydrates on Bush Hill, Gulf of Mexico (MacDonald et al., 1994). D. From gas hydrates sampled on the Buzdag mud volcano in the Caspian Sea (Ginsburg and Soloviev, 1994). 